\title{
Experiences of women who use crack
}

\author{
Vivências de mulheres que consomem crack
}

Vivencias de mujeres que consumen crack

Vania Dias $\mathrm{Cruz}^{1}$, Michele Mandagará de Oliveira ${ }^{1}$, Valéria Cristina Christello Coimbra ${ }^{1}$, Luciane Prado Kantorski ${ }^{1}$, Leandro Barbosa de Pinho² ${ }^{2}$ Jeane Freitas de Oliveira ${ }^{3}$

This study aimed to understand better the experiences of women who consume crack. It is a qualitative research conducted through a semi-structured interview with 16 women registered in the Estratégia de Redução de Danos de Pelotas/RS [Harm Reduction Strategy of Pelotas/RS/Brazil], in 2012. For data analysis, one used the content analysis, in the modality thematic analysis, from the perspective of gender relations. The results were grouped into two categories: prejudice, prostitution and crime situations and family and friends relationships. One identified women labeled by society as criminals who suffer daily with situations of prejudice, for not having a behavior socially and culturally expected for women, such as being docile and fragile. Adverse events during childhood were identified, however, there was a network of solidarity among people who consume this drug. Based on genders, it can be seen the concrete and symbolic organization of these women's social life and the connections of power in gender relations.

Descriptors: Drug Users; Crack Cocaine; Women; Gender Identity.

Objetivou-se conhecer as vivências de mulheres que consomem crack. Pesquisa qualitativa, realizada por meio de entrevista semiestruturada, com 16 mulheres cadastradas na Estratégia de Redução de Danos de Pelotas, RS, Brasil, em 2012. Para análise dos resultados, utilizou-se a análise de conteúdo, na modalidade análise temática, sob a ótica das relações de gênero. Os resultados foram agrupados em duas categorias: Preconceito, prostituição e situações de criminalidade e Relações familiares e de amizade. Identificaram-se mulheres rotuladas pela sociedade como criminosas e que sofrem com situações de preconceito diariamente, por não apresentarem comportamentos sociais e culturalmente esperados para as mulheres, como sexo dócil e frágil. Eventos desfavoráveis durante a infância foram constatados, no entanto, identificou-se uma rede de solidariedade entre as pessoas que consomem essa droga. A partir do gênero, pode-se perceber a organização concreta e simbólica da vida social dessas mulheres e as conexões de poder nas relações entre os sexos.

Descritores: Usuários de Drogas; Cocaína Crack; Mulheres; Identidade de Gênero.

El objetivo fue conocer experiencias de mujeres que consumen crack. Investigación cualitativa, por medio de entrevista semiestructurada, con 16 mujeres registradas en la Estrategia de Reducción de Daños de Pelotas, RS, Brasil, en 2012. Para análisis de los resultados, se utilizó el análisis de contenido, en la modalidad análisis temático, basada en las relaciones de género. Los resultados se agruparon en dos categorías: Prejuicios, prostitución y situaciones de criminalidad y Relaciones familiares y de amistad. Se identificaron mujeres etiquetadas por la sociedad como criminosas y que sufren con situaciones cotidianas de prejuicios, por no presentaren comportamientos sociales y culturalmente esperados para mujeres, como docilidad y fragilidad. Eventos desfavorables en la niñez fueron constatados, sin embargo, hay una red de solidaridad entre aquellas que consumen esta droga. Del género, se percibe organización concreta y simbólica de la vida social de estas mujeres y conexiones de poder en las relaciones de género.

Descriptores: Consumidores de Drogas; Cocaína Crack; Mujeres; Identidad de Género.

\footnotetext{
${ }^{1}$ Universidade Federal de Pelotas. Pelotas, RS, Brazil.

${ }^{2}$ Universidade Federal do Rio Grande do Sul. Porto Alegre, RS, Brazil.

${ }^{3}$ Universidade Federal da Bahia. Salvador, Bahia, Brazil.

Corresponding author: Vania Dias Cruz

Barão de Azevedo Machado, Bl - 623 A, Apto 21, Centro CEP: 96020150. Pelotas, RS, Brazil. E-mail: vânia_diascruz@hotmail.com
} 


\section{Introduction}

This article, whose theoretical and philosophical reflection was based on gender relations, addresses issues related to the experiences of women who use crack.

This is a survey conducted by the Oswaldo Cruz Foundation in partnership with the Secretary of National Policies on Drugs with a population of 7,381 people who use crack and/or similar drugs in Brazil, which found out that the consumption of this substance prevails among men with an average age of 30 years old, "non-white", unmarried, with low education (4th to 8th grade of elementary school), who are on the streets and working informally. Regarding the consumption of psychoactive substances among women, it was identified that about $10 \%$ were pregnant and more than half had been pregnant at least once after starting the consumption of crack, $29.9 \%$ practiced prostitution and $44.5 \%$ reported having suffered sexual violence ${ }^{(1)}$.

The consumption of crack and other psychoactive substances among women is still poorly investigated in Brazil. Information of national bases highlight barriers of structural, social, systemic, cultural and personal order faced by this population to seek treatment and assistance to health ${ }^{(2)}$. Prejudice and stigma of health professionals towards women who use psychoactive substances are a political and financial concern because social disapproval contributes to the maintenance of consumption in secret, increasing vulnerability to various risks and damage to health ${ }^{(2)}$. Furthermore, as the use of crack has been increasing, differences in the culture of use have also occurred, because many women practice prostitution as a means of obtaining psychoactive substances ${ }^{(3-4)}$.

Women who consume psychoactive substances, including crack, have specific and unique needs that need to be identified and recognized by nurses and other health professionals, from the perspective of gender, in their practice, justifying this study. These situations and needs, in general, are associated with the standard of crack consumption; pregnancy; responsibilities in the care with children; sex work; trauma resulting from physical and sexual abuse; high levels of mental health problems; low self-esteem and stigma because of the social role of "being a woman"(2).

Accordingly, the gender perspective has been identified as a powerful approach in order to recognize the impact of crack use in society, being understood through systems of signs and symbols that highlight the power relations between people ${ }^{(5)}$. In this research, gender is understood as a constitutive element of social relationships, and it is considered the first way to give meaning to the relations of power, through which it is possible to decode and understand the complex relationships present in human interactions ${ }^{(6)}$.

Accordingly, it was questioned: What are the experiences of women who use crack? Starting from the research question presented, this article aimed to understand the experiences of women who consume crack.

\section{Method}

This is a qualitative research with 16 women registered in the Harm Reduction Strategy of PelotasRS-Brazil. The strategy is part of the organizational chart of the City Health Department and it is linked to the Management of Sexually Transmitted Diseases Program, being organized and understood from the perspective of the Harm Reduction Program.

The indication of participants was made by a Harm Reduction Team, which operates in the Harm Reduction Strategy, according to the following inclusion criteria: being female, over 18, being registered in the service because of crack consumption, currently and/or at some point in life. The selection of participants occurred intentionally, according to who was at home and in the different access points of the harm reduction agents.

Data were collected in January 2012, by applying semi-structured interviews, guided by a 
predefined script elaborated with issues related to the experiences of crack consumption. The interviews were conducted during the fieldwork of the Harm Reducing Agents in different neighborhoods of the city, providing opportunities to know the context of the participants. Out of the 16 interviews, 13 were conducted in the women's place of residence, two in a house for the consumption of crack and one at her workplace (car keeper), downtown. There was neither prior contact nor schedule with the participants and the purpose of the research was explained at the time of the interview.

Each interview took an average of 45 minutes. To ensure the reliability of the speeches, the interviews were recorded through an electronic device and transcribed. The anonymity of the participants was ensured through their identification by the use of the letter I (interviewee) followed by the number indicating the interview. Thus, the first respondent obtained the coding I1 and the last I16.

Data analysis was based on content analysis, in the thematic analysis modality ${ }^{(7)}$ from the perspective of gender relations ${ }^{(6,8)}$. Thus, the data were analyzed in three distinct phases: previous analysis, material exploration, data processing and interpretation ${ }^{(7)}$.

During the pre-analysis there was the organization of the data obtained from the interviews, including: transcription, reading, organization of the material and resumption of initial hypotheses and research objectives; during the exploration of the material there was the data classification through the exhaustive reading of data that came from the interviews, identifying main ideas and empirical categories, resumption of literature review about women who consume crack in the gender perspective and the establishment of a "corpus" which was reassembled according to the category experiences of women who consume crack; the treatment of results and interpretation was marked by the moment the researcher proposed the inferences and made interpretations according to gender relations ${ }^{(7)}$.

Regarding the construction of gender relations, it is composed of four key elements that interrelate and influence the socio-cultural processes: 1) there are symbols constructed culturally that evoke multiple and often contradictory representations that are not necessarily exclusionary; 2) there are normative concepts that show evidence and interpret symbols expressed through religious doctrines, scientific and educational productions; 3 ) it is highlighted that gender is constructed in kinship systems, in economy and political organization, acting independently; 4 ) it is necessary to evaluate how gender identities are constructed and relate to organizations and historically situated social representations ${ }^{(6)}$.

Throughout the development of the research precepts of the Resolution number 466/2012 from the National Health Council were followed, respecting the anonymity of the women studied. The project received approval from the Research Ethics Committee of the Nursing College from the Federal University of Pelotas under protocol number 63/2011.

\section{Results}

The results of this study were grouped into the following categories: prejudice, prostitution and crime situations and family and friends relationships. The women interviewed are mostly black or brown, are between 19 and 48 years old, are in a disadvantaged social and economic situation, work informally, have a partner and have at least one child.

\section{Prejudice, prostitution and crime situations}

For the participants, women who consume crack are labeled by society as criminals, sex workers and irresponsible. These labels are not consistent with patterns of social behavior culturally expected for women, which are seen as a docile and gentle gender. In this context, they experience situations of prejudice daily. From the conception of gender some behaviors are defined by culture as belonging to another gender, to which men and women must anchor their behaviors 
to be recognized as such. A woman who smokes crack is labeled as a prostitute, and it is not like that, I work if I have to work. Men are considered thieves, and I know many workers who are crack users, many fathers that no one would imagine. We are labeled by society (I4). If a woman goes out of the neighborhood, people look at her differently and if the woman is skinny, they say she is a crackhead or that she is prostituting herself to buy crack (I13). If for men using crack is bad, imagine for women? It's worse when they have children because sometimes I left my daughter with my mother and threw myself into madness (I15).

When trying to impose more respect and, consequently, to protect themselves from violence of the streets, the adoption of measures such as having their hair cut and getting dressed with men's clothes was reported by one of the research participants. Such behavior is characterized as a transgression to genres in which women would emancipate themselves through the release of some male aspects of their personalities. Women who use crack are very battered on the streets. I used to wear a cap, a loose t-shirt and hold a bottle of rum; I used to fight like a man to defend myself because otherwise they would steal my crack, my rum or my money and beat me for being a woman, for being an easy target, I learned to defend myself(I3).

Involvement with prostitution was pointed by the majority of the participants, confirming it primarily as a way to support themselves and then as a way to acquire the desired drug. According to reports, the sale of the body was symbolized by some women as a strategy that gives them autonomy, power and some advantages over men, especially for the purchase of drugs. Many men see women as trash and women take advantage of that. For women it is easier to use the drug, they only need to have sex or sell their bodies, but men, if they don't take money or if they don't sell drugs, they don't get it (I5). I've never sold my body for less than \$ 50.00 and I always say that I don't trade my body for a stone. I do this for a living, I have my addiction, but that's not why I use my body (I6). If I had a job, I would not be in this (prostitution), I want to get out, I want a job, if I get one I'll stop everything (psychoactive substances) (I7).

Most women deny engaging in criminal activities, highlighting not needing to steal to get money or even the crack itself. I have to find myself in this crazy world that is mine, I am not a person who steals. I have to show the respectful person that I am, even using drugs or prostituting myself, because it comes from my effort, I don't get anything from anyone (I6). I've never stolen, I never will, I want to die blowing a whistle. To use drugs one doesn't need to steal, he doesn't need to do wrong things (I16).

Theft and dealing of psychoactive substances were practices adopted by some participants at some point in life to buy drugs, according to the following reports. I smoked more than I sold it. Around the block where I worked some guys looked for me to get it (crack) (I1). I stole 2,500 reais from an ex-husband, he was a drug dealer, I smoked it in two weeks alone (I2). There was a time that I robbed stores (clothes). I was much younger (I9). Society thinks we do not use crack, but women are worse than men. My mother came to live here and left because I took everything from her, all her money (I11).

\section{Home and the streets: friends and family relationships}

Family problems are present in the lives of some women who consume psychoactive substances, however, it is perceived by the reports that the triggering factor for such a situation did not occur due to the use of crack. Ways of life in contemporary families have been changing, creating new articulations of gender and generations, developing new codes. It has expanded the possibilities of women in the social world, shaking the family ties and getting larger, many women have been adopting behaviors that were common only among men, showing stronger resistance to the imposition of limits for the simple fact of being men or women. I don't know my biological parents, I lived with my foster mother until I was 10 years old, From 5 pm on I could not go out because I was a girl, then I ran away from home, had my baby when I was 11 to 12 years old and went to the streets (I7). My dad left home when I was 5 years old. My mother drank alcohol, I left home when I was about 12 years old because I didn't get along with my stepfather. I had problems with my family since I was born, using crack or not (I8). I left home because my father used to beat me, I started to work as a babysitter, but my father's friends found me, they told him and to took me home. But he started to beat me again and I ran away again (I9). 
Unlike existing troubled relationships with family members, there seems to be a network of solidarity and kinship with people who also consume crack. Even nowadays it is noticed that there is a differentiation between the sexes regarding the identity of male and female. Not only women learn to be feminine and submissive, but also men are watched in maintaining their masculinity and protection of these "helpless women". I made a lot of friends on the street and I have still today, I was very respected by the little crooks, but because I did not steal the drug from them. I took care of their pipe and I was friendly. I slept on the side of a beggar and he took care of me because I was a woman, because a stranger could appear and try to grab me (I3). My son, the girls and the boys I met here are the family I met, we get along well (I16).

\section{Discussion}

From different ways, the respondents live with violence, crime, drug dealing and consumption of crack and other drugs as practices of daily nature. These practices are understood by an active behavior against the prevailing social values in society, in which women are considered frail, passive, submissive and solely responsible for the care of children and family ${ }^{(9)}$. Strategies of resistance represent a response to oppression and contradictions that the oppressed ones are exposed to, and the acceptance of appropriate sexual behavior or culturally determined roles is rare. Thus, the consumption of psychoactive substances shows resistance to oppression and, in parallel, denounces the myth of female passivity ${ }^{(10)}$.

In an attempt to demarcate resistance to social and cultural oppression, the women interviewed experience situations of discrimination generated by prejudice related to the consumption of drugs and the actions linked to this behavior, such as prostitution, fruits and theft, and especially lack of responsibility with their children. Prejudice reinforces the marks of social class division and preserves the power relations of men over women, constructed in society and based on roles, identities and normative behaviors that influence the construction of gender relations. Thus, prejudice generates situations of vulnerability to social and health hazards.

The gender is responsible for giving meaning to the distinctions between the sexes, for it transforms beings biologically made male and female into men and women, social beings. The differentiation between the sexes assumes the characteristics that constitute the identity of masculine and feminine, ie, not just women learn to be mothers, feminine and submissive, and are controlled by it, but men are watched in maintaining their masculinity and virility ${ }^{(6)}$.

Gender relations identified as power relations are marked by hierarchies, disobedience and inequalities, in which are present multiple strains of negotiation, cooperation, conflict and alliances, not only in reducing relations of domination of one group over another. Power must be understood as a mechanism that through ceaseless struggles, transforms, reinforces and reverses them, either through the maintenance of male power, or through the struggle of women for expansion and pursuit of that power ${ }^{(6)}$.

A study in Spain with a group of women who use psychoactive substances confirmed the existence of role conflicts or uncertainties as to the functions assigned to being a woman, because when they decide to take time for themselves, for their pleasures, they feel guilty or are judged by society because they are not fulfilling their role of good mothers and housewives. In this perspective, the consumption of crack can be understood as a strategy to face and try to transform a life marked by discrimination, being limited to a constant search for pleasure focused only on the present ${ }^{(9)}$.

Though culturally the status of women who consume psychoactive substances is full of stigma and prejudice, each one of them lives in a different situation, and it is not ideal to see them as a group of "drugged", as in this category they may appear in different ways, such as: adolescents, pregnant, married, single and gay, finally, each one of them has their own lifestyle, 
in which their worldview can be diverse ${ }^{(3.8)}$. That way, when analyzing subjective processes of people living in a particular context, it is necessary to recognize the existence of specific features, and avoid turning a single element into the group's identity ${ }^{(6)}$.

Faced with conflicting concepts the population tends to consider them as antagonistic, if they choose one, they automatically ignore the other, such as equality versus difference and individual versus group, however Joan Scott argues that treating such concepts as excluding means missing the point of their interconnections; these terms should be treated as paradoxes, which are interdependent and in constant tension and not opposition ${ }^{(6)}$.

The use of male clothing in order to defend themselves from threats present on the streets allows one to understand that gender relations, understood as power relations, are in constant transformation, being influenced by interpersonal and intergroup relationships, policies, forms of leadership and cultures, which can strengthen or require changes in attitudes and behaviors from people ${ }^{(6)}$. In this sense, it is noticed the existence of constant and dynamic flows of gender relations, in which the context of the streets demanded from these women a new subjective identity.

Certain behaviors are defined by culture as belonging to one sex or another, on which men and women should base their behavior to be recognized as such, representing a transgression of gender the release of some male personality aspects of women (work, clothing, competition) and some feminine of man's personality (affection, responsible parenthood, beauty and home care) ${ }^{(6)}$.

Through the interviews, it is noticed that some women become involved in prostitution due to financial necessity, while others trade their bodies for stones or the corresponding value to support their addiction. A study conducted with female sex workers who use crack identified that the life they lead is extremely stressful, being exposed in their workplace to various hazards such as harassment by criminals, intimidation by their clients and leaders (pimps) as well as threats of violence by their own regular partners, and usually the consumption of crack is considered essential in order to face these situations ${ }^{(4)}$.

Many women engage in prostitution for not having a job and a decent income, and there are many socioeconomic and psychological determinant factors, including: migration to urban centers, lack of employment, involvement with psychoactive substances, subhuman living conditions, poor education, lack of life projects and perspectives, childhood trauma and the lack of family support ${ }^{(11)}$.

However, a study that aimed to reflect on the mutual implications of the possible relationship between female prostitution and sexual rights as political fields defends the existence of women who engage in prostitution for pleasure and the quest for financial autonomy, and highlighted that these women understand the risks of prostitution and substance use differently from those people who do not have this activity. While for health professionals such practices are considered of high risk, for sex workers they mean fun and relaxation and are often part of the social context in which they are inserted ${ }^{(12)}$.

The issue involving sexuality of sex workers is complex, as it is subjected to different hierarchies that articulate with the visions of gender and work, producing unique forms of oppression. But the fact of engaging in prostitution offers possibilities of questioning, resistance and struggle. Thus, saying that a prostitute is subjected to "sex with strangers" is not understanding the logics of refusal and pleasures that underlie these relationships, in which the woman has the power to sell her body ${ }^{(6,12)}$.

In this research, one identified women who prefer to engage in prostitution rather than selling psychoactive substances or stealing. A study with sex workers in the city of Coxim, Mato Grosso do Sul, Brazil, identified that the involvement of women in prostitution, although morally disapproved, compared to the dealing of psychoactive substances and/or theft 
is seen by them as an heroic attitude, a way out for survival and a dignified way to earn a living because they prefer prostitution to engaging in crime ${ }^{(13)}$.

In this context, prostitution can be understood as a women's protection measure against the involvement in crime, explaining the domain that they have on their bodies, which is sold in order to get what they need. In this perspective the body appears as a privileged element of manifestation of power, setting up a practice of empowerment of women in relation to men, who may only have access to their bodies by paying for sexual services, highlighting strong gender relations.

Feminism has showed for a long time the development of gender identities related to the passivity of values and conservative attitudes imposed by society, but lately women have been giving an active response to social contradictions to try to solve the antagonistic messages they receive. Thus, prostitution can be interpreted as a protest of dissatisfaction and discontent to the oppressive situations they experience, showing the ability of female domination $^{(10)}$.

The complexity of the phenomenon of psychoactive substances use is linked to social, political and moral ties ${ }^{(11)}$. Women who consume crack are seen by society as "deviant", serving as markers that divide women between good and bad. From this perspective, there is a continuum that, on the one hand, values the "correct" good mothers, daughters, wives and housewives, and on the other hand, refuses women who go to the opposite direction, such as lesbians, single mothers, users of psychoactive substances and sex workers ${ }^{(3,14)}$.

Regardless of the reason for involvement in prostitution, when this practice occurs associated with crack use, it increases vulnerability to contamination with sexually transmitted diseases ${ }^{(4)}$. It is necessary to perform actions that can mitigate this situation and prevent risks to the health of those involved. However, facing this problem is often hampered by prejudice, in which subjects blame the causes of a social problem as if they were moral failures ${ }^{(15)}$.

Regarding crime, the women interviewed do not usually get involved in this type of practice, allowing them to retain some sense of order in their lives, demonstrating that they can rule their lives independently of the consumption of psychoactive substances and breaking the taboo that all people who use crack are violent, criminal and dependents ${ }^{(15)}$.

The discussions related to the smaller number of women who engage in criminal practices, when compared to men, seem to be related to the roles of women and specific forms of gender control, being considered as contributing factors to the noninvolvement in crime: the way women are taught to behave; the socialization of girls focused on caring for the other, being considered as a "shield" against crime and the representations remaining in society that deviant behaviors are natural among men, supporting the difference between the sexes is still a reality ${ }^{(3)}$.

In addition, women have another weapon in their hands for earning money considered more potent and less criminal: prostitution. It is perceived by the speeches that women who prostitute themselves rarely commit crimes, thus not being considered criminal offenders, according to their opinions.

In 2006, from the legal point of view, a differentiation between criminals and people who consume psychoactive substances started to be made, establishingrulestosuppressunauthorized production, the illicit dealing of psychoactive substances and defining crimes. However, this phenomenon becomes complex as there are inconsistencies between this law and the comprehensive attention policy for users of alcohol and other drugs ${ }^{(16-17)}$.

On the one hand, there is a health care policy that understands a person who consumes psychoactive substances as a citizen of rights, and these rights should not be denied because he uses drugs, on the other hand, there is a law on psychoactive substances $(11,343 / 06)$ that penalizes this behavior and criminalizes the act of consuming these substances ${ }^{(16-17)}$. 
Hence, women who consume crack and prostitutes themselves are considered less dangerous than those who commit crimes to maintain their addiction. However, the difficulty in differentiating these people cause problems in clinical practice because the political model itself ends up putting the user into lawlessness and justice measures appear as issues to be solved in health care ${ }^{(18)}$.

Some women reported engaging in theft practices (I2, I9 and I11) and drug dealing (I1). People who consume crack compulsively tend to engage in petty thefts, robberies and depredations of public property due to the imminent desire to use more $\operatorname{crack}^{(19)}$. A study with patients from the Center for Psychosocial Care about Alcohol and Drugs of Sobral, Ceará, Brazil, in 2010 found out that $6.7 \%$ of users had problems with the law and $5.7 \%$ with the police, possibly due to attempts to achieve goods or cash to illegally purchase drugs or because of notification in conflicts and fights ${ }^{(20)}$.

In the present study, the theft was a practice characterized by robbing relatives and companions and thefts in shops and to the population in general, being motivated for living in context of extreme poverty, for these women's personality characteristics and for buying crack.

In this sense the crime should be understood as a complex phenomenon, reflecting a culture of violence and political and economic survival in many places and contexts. Contrary to what is reinforced by the media, people who consume crack do not always commit crimes due to substance use, but due to their life structure and the social context in which they are subjected $^{(18)}$.

Women's involvement with crack dealing was also identified in this research. Managers of public safety and the majority of academic research consider the involvement of women in the dealing of psychoactive substances as a deviant behavior associated with hopelessness, prostitution, and especially affective marital bonds with partners who commit crimes, usually being men the leaders and they are just supporters ${ }^{(21)}$.

However, one realizes that women have been assuming leadership roles in the dealing of psychoactive substances and other criminal practices. A woman who engages in drug dealing has power over the others and seeks her role in the social world. The changes that occurred in the formal labor market and in society in general also reflect on the illicit market, in which many women feel empowered when they take leadership positions in drug dealing and for not needing to prostitute themselves to acquire money and/or crack, marking major behavioral changes in the design of masculinity and femininity.

A survey with eight women who had a history of involvement in the drug dealing network in Rio de Janeiro found out that different contexts are responsible for the insertion of these women in this practice, including: the lack of opportunities in the formal labor market, the opportunity to belong to a network of sociability, the desire for status and power in a masculine culture and the strong presence of drug dealing in poor communities ${ }^{(21)}$. Among these motivations, the power status showed prominent among women, suggesting that their involvement in drug dealing differs them from the others, once they experience the power formerly known only by men ${ }^{(21)}$.

From this perspective, it is interesting to highlight the new insertions of women in society that goes beyond the standard roles, suggesting a change of gender concerning to masculine/feminine, public/ private and active/passive $\mathrm{e}^{(6)}$.

The centrality of criminal practices as masculine activities, circulating in the media discourse, tends to silence and make invisible the understanding of women in this phenomenon, and there are no real public policies that consider the specific characteristics of women involved in crimes, reinforcing the association of women to passivity and victimization $^{(21)}$.

The presence of violence, parents' separation and use of psychoactive substances among family members was found as common practices in the 
childhood of the study participants, denoting fights and people running away from home still in their childhood and explaining the existence of disturbed family relationships, without association with the consumption of crack.

Several adverse events in the family environment are able to act as inducers in the involvement of young people with substance abuse, namely: loss of a family member, consumption of alcohol and other psychoactive substances among family members; fights and separation from parents and the presence of physical and psychological domestic violence ${ }^{(22)}$. In this context, it may be suggested that family conflicts present in the lives of the women of this study contributed to their involvement with crack and other psychoactive substances.

The characterization of people who consume crack is usually related to social isolation or conflict and violent acts $^{(15)}$. However, the present study identified a network of solidarity among people who consume crack formed from the establishment of help relationships and alliances around a common goal, thus building a new family.

An ethnographic survey with a population of streets in Pelotas-RS-Brazil found out that different desires, interests and trajectories converge on the need to establish a network of social and symbolic relations, because this population needs the support of others in order to explore the streets as a possible social space. Thus, one can infer that the person who consumes crack, as well as the others who are on the streets, are excluded from the rest of society and therefore tend to come together and share information and care, creating a solidarity network in order to protect themselves ${ }^{(23)}$.

These statements are contrary to the assumption that people living on the streets and consuming crack are marked only by processes of loss, separation and isolation, on the contrary, many learn to give new meaning to their lives, acquiring new attitudes and fundamental behavior patterns of those who suffer daily with discrimination and prejudice and survive in precarious living conditions. Such attitudes are marked by the sharing of food, shelter and even a crack stone ${ }^{(23)}$.

Paradoxical aspects in gender relations could harm women's status. Faced with conflicting concepts people tend to consider them as antagonistic, if they choose one, they automatically ignore the other, for example, a woman who uses psychoactive substances versus a responsible woman, homeless versus worker. Thus, treating such concepts as exclusionary means to miss the point of their interconnections; these terms should be treated as paradoxes, which are interdependent and in constant tension and not opposition.

\section{Conclusion}

The research has helped understand the experiences of women who use crack, identifying characteristics that deserve to be published and recognized by nursing/health professionals seeking assistance based on gender relations built in our society.

Data analysis from the perspective of gender relations allowed one to know that every woman who consumes crack is permeated by specific characteristics, responsible for producing and transforming circumstances and concrete experiences according to her needs, will and the creating of powers and/or counter powers.

It is evident the complexity of the problem of crack use by the female population, being necessary a greater investment in research that deals with this issue in order to contribute to the production of knowledge, strengthening and coordination of health services and the development of new alternatives to confront this social reality.

The data show that the consumption of crack by the interviewees is related to a quest to confront the different forms of oppression and few perspectives of change in their lives, generated mainly by situations of social inequality and the consumption of alcohol 
and other psychoactive substances among family members. This research allows one to sensitize nurses/health professionals to women who consume crack in order to overcome the barriers of stigma that prevent the approach with these people and hinder the achievement of a quality health care.

\section{Collaborations}

Cruz VD and Oliveira MM participated in the study design, collection, analysis, interpretation of data and drafting of the article. Coimbra VDC, Kantorski LP, Pinho LB and Oliveira JF participated in the construction of the project, review, writing and critical analysis of the article.

\section{References}

1. Ministério da Saúde (BR). Fundação Oswaldo Cruz. Secretária Nacional de Políticas sobre drogas. Estimativa do número de usuários de crack e/ou similares nas Capitais do País. Brasília: Fiocruz; 2013.

2. Oliveira JF, Paiva MS, Valente CLM. A interferência do contexto assistencial na visibilidade do consumo de drogas por mulheres. Rev Latino-Am Enfermagem. 2007; 15(2):247-52.

3. Pardo LS. Género y drogas: Guía informativa: drogas y género: Plan de Atención Integral a la Salud de la Mujer de Galicia. Galicia: Subdirección Xeral de Saúde Mental e Drogo dependencias; 2009.

4. Malta M, Monteiro S, Lima RMJ, Bauken S, Marco A, Zuim G.C, et al . HIV/AIDS risk among female sex workers who use crack in Southern Brazil. Rev Saúde Pública. 2008; 42(5): 830-7.

5. Moraes M. Gênero e usos de drogas: porque é importante articular esses temas? In: Moaraes M, Castro R, Petuco D. Gênero e drogas: contribuições para uma atenção integral a saúde. Pernambuco: Instituto PAPAI/Gema/UFPE; 2011. p.15-20.

6. Scott JW. Gênero: uma categoria útil de análise histórica. Rev Educ Realidade. 1990; 16(2):5-22.

7. Minayo MCS. O desafio do conhecimento: pesquisa qualitativa em saúde. São Paulo: Hucitec; 2010.

8. Scott JW. 0 enigma da igualdade. Rev Estud Fem. 2005; 13(1):11-30.

9. Romo AN, Gil GE. Género y uso de drogas: de lailegalidad a lalegalidad para enfrentar elmalestar. Rev Trastornos Adict. 2006; 8(4):24350 .

10. Borges MTT, Barbosa RHS. As marcas de gênero no fumar feminino: uma aproximação sociológica do tabagismo em mulheres. Cienc Saude Coletiva. 2009; 14(4):1129-39.

11. Aquino PS, Nicolau AIO, Pinheiro AKB. Desempenho das atividades de vida de prostitutas segundo o modelo de enfermagem de Roper, Logan e Tierney. Rev Bras Enferm. 2011; 64(1):136-44.

12. Olivar JMN. Prostituição feminina e direitos sexuais... diálogos possíveis? Sexualid, salud e sociedade. Salud Soc. 2012; (11):88-121.

13. Amorim ML, Dias FGA. Retratos falados das trabalhadoras sexuais de Coxim. Rev rascunhos culturais [internet]. 2010 [citado 2012 nov 06]; 1(1):111-21. Disponível em: http://revistarascunhos.sites.ufms.br / files/2012/07/1ed_artigo_8.pdf

14. Rodrigues LSA, Paiva MS, Oliveira JF, Nóbrega SM. Vulnerability of women in common-law marriage to becoming infected with HIV/AIDS: a study of social representations. Rev Esc Enferm USP. 2012; 46(2):349-55.

15. Raupp L, Adorno RCF. Jovens em situação de rua e usos de crack: um estudo etnográfico em duas cidades. Rev Bras Adolesc Conflitualidade. 2011;(4):52-67.

16. Ministério da Saúde (BR). Secretaria Executiva. Coordenação Nacional de DST/Aids. Política do Ministério da Saúde para atenção integral a usuários de álcool e outras drogas. Brasília: Ministério da Saúde; 2003.

17. Brasil. Lei № 11.343, de 23 de agosto de 2006. [Internet] 2006 [citado 2011 nov 03]. Disponível em: http://www.planalto.gov.br/ccivil_03/_ ato2004-2006/2006/lei/l11343.htm

18. Malheiro LSB, Macrae E. Trabalho de campo e a construção de políticas para usuários de drogas - a questão dos usos de crack na atualidade: um olhar sobre usuários e usuárias. In: Moraes M, 
Castro R, Petuco D. Gênero e drogas: contribuições para uma atenção integral a saúde. Pernambuco: Instituto PAPAI/Gema/UFPE; 2011. p.53-8.

19. Dualib LB, Ribeiro M, Laranjeira R. Perfil dos usuários de cocaína e crack no Brasil. Unidade de Pesquisa em Álcool e Drogas (UNIAD) Universidade Federal de São Paulo. [Internet] 2008 [citado 2012 nov 03]. Disponível em: http://www.uniad.org.br/desenvolvimento/ images/stories/publicacoes/cocaina/Perfil_dos_ usuarios_de_cocaina_e_crack\%202007.pdf

20. Oliveira EN, Silva MWP, Eloia SC, Mororó FWP, Lima GF, Matias MMM. Characterization of the clientele attended in a psychosocial care center alcohol and drugs. Rev Rene. 2013; 14(4):748-56.
21. Barcinski M. Protagonismo e vitimização na trajetória de mulheres envolvidas na rede de tráfico de drogas no Rio de Janeiro. Cienc Saude Coletiva. 2009; 14(2):577-86.

22. Bernardy CCF, Oliveira MLF. The role of family relationships in the initiation of street drug abuse by institutionalized youths. Rev Esc Enferm USP. 2010; 44(1):11-7.

23. Silva TL. A rua como espaço de interação social: um estudo antropológico das relações entre população em situação de rua e grupos caritativos. Antropolítica: Rev Contemp Antropol [internet] 2011 [citado 2012 out.10]. Disponível em: http://www.revistas.uff.br/index. php/antropolitica/article/view/41/pdf 